\title{
ENHANCING PLEA BARGAINING PROCESS THROUGH MEDIATION
}

\author{
Norjihan Ab Aziz ${ }^{1 *,}$ Noorshuhadawati Mohamad Amin'² and Zuraini Ab Hamid ${ }^{3}$ \\ ${ }^{1}$ Assist. Prof. Dr., International Islamic University Malaysia, Malaysia, norjihanabaziz@iium.edu.my \\ ${ }^{2} \mathrm{Ph}$.D student, International Islamic University Malaysia, Malaysia, shuhadaamin@iium.edu.my \\ ${ }^{3}$ Assist. Prof. Dr., International Islamic University Malaysia, Malaysia, zuraini.abhamid@gmail.com \\ ${ }^{*}$ Corresponding author
}

\begin{abstract}
Plea bargaining is an out of court process which allows the accused to plea for reduction of a charge or sentence for an offence that he had committed. It is a common practice among the accused and the prosecutor to expedite the disposal of criminal case. It benefits the prosecutor to secure the punishment of the accused without proceeding to a full trial, which needs a certain procedure and a higher standard of proof to prove the accused guilty of an offence. Through plea bargaining, the accused will not be subjected to severe charge or punishment, and the prosecutor and the accused cannot appeal the case to the higher court if plea bargaining is successful. Nevertheless, the process of negotiation without the assistance of a third party could lead to the unsuccessful of plea bargaining which may result to a full trial. This happens if the prosecutor or the accused disagree with the sentence or a new charge offered by any one of them. This will cause inconvenience to the accused if he initially agrees to plea bargaining for reduction of the charge or sentence, however, due to the dissatisfaction of the suggestion of a new charge or sentence offered by the accused, the prosecutor tends to proceed the case to a full trial. This can be avoided if a neutral third party assists the accused and the offender to reach a deal. For instance, in Singapore a judge acts as a mediator to facilitate the process of plea bargaining to resolve criminal cases out of court. Thus, this research examines how plea bargaining is conducted under the Criminal Procedure Code of Malaysia. It also analyses how mediation helps plea bargaining process under the law of Singapore. It is suggested that the Criminal Procedure Code of Malaysia be amended to allow a third party to facilitate the process of plea bargaining.
\end{abstract}

Keywords: plea bargaining, mediation, punishment

\section{INTRODUCTION}

Plea bargaining is an alternative criminal settlement out of court. It normally applies between the prosecutor and the accused at the pre- trial process. The successful plea bargaining process reduces the number of pending cases, appeal cases and helps expedite the disposal of criminal cases. This benefit the prosecutor 
as the prosecutor can secure the charge and punishment against the accused. At the same time, it benefits the accused by not be subjected to severe punishment. Nevertheless, the Court has to be fair between the interest of the public at large and the interest of the accused. The punishment imposed though lesser than the original punishment as stated in the Penal Code, the Court has to observe the principle of proportionality to decide punishment on the accused.

Nevertheless, mediation is more structured than unassisted negotiation (Laurence and Nesic, 2001,35). Hence, plea bargaining without a third party is unstructured. A mediator helps to manage procedures during negotiations in plea bargaining between the accused person and the prosecutor, including identifying the needs and interests of the parties, narrowing options and provides ways in dealing with the dispute (Laurence and Nesic, 2001,12). It is not easy to reach a mutual agreement on plea bargaining without the help of a trained mediator. A mediator could assist the parties to exchange the information, find the options and reach a mutual solution. Once the agreement is reached, the case will be disposed of by the judge based on what the accused and the prosecutor have agreed upon (Kimberlee, 2008, 140).

There are weaknesses in plea bargaining without the assistance of the mediator during the process of negotiation. The process of plea bargaining merely involves the prosecution and the accused or the advocate, thus, there is no transparency in the process without a third party to oversee the process. Besides, there are two conflicting interests between the prosecutor and the accused. The prosecutor's interest is to safeguard the public interest by issuing serious charge and sentence, but the accused's interest is to be charged with a lesser offence and a light sentence (Gabriell, 2009). Furthermore, the court only examines volunteer of the accused when the accused applied for plea bargaining, not the whole process of plea bargaining.

It is submitted that there are cases where the accused intends to apply for plea bargaining, but he is referred to the court for trial due to no agreement reaches between the accused and the prosecutor. The accused who applies for plea bargaining is indicative that he wishes to be imposed with a lenient sentence. However, if no agreement can be reached between the accused and the prosecutor, the case will be referred to trial. The consequence is that the accused cannot be subjected to a lenient sentence as provided under the plea bargaining.

These weaknesses can be overcome if the process of plea bargaining is enhanced by incorporating mediation in the process. The presence of the judge acts as a mediator could assist the parties in reaching a mutual agreement. The judge having experience in criminal cases could hear from both parties matters relating to the charge, facts and any issues raised. This can preserve transparency in the plea bargaining process as the mediator has to be a neutral person to both parties, and listen to each needs and interests. The mediator will ensure that if plea bargaining takes place, the accused pleads guilty voluntarily and understand the nature of the offence charged as well as the effect of the plea. The presence of a mediator could assist the parties to reach a mutual agreement by making an indication as regard to the sentence that will be imposed on the accused if he pleads guilty in plea bargaining process or by allowing the parties to make suggestions with respect to the sentence and the mediator imposes the sentence within the range agreed with the parties (Maureen, 2004, 571). Thus, criminal mediation helps the parties and the Court to expedite disposal of criminal cases, reduce pending cases and appeal cases. Since sentence imposed by the mediator or the judge is mutually agreed by the parties, this can avoid trial and appeal cases. The trial is only necessary if criminal mediation fails.

\section{DEFINITION OF PLEA BARGAINING}

Plea bargaining is a negotiation process between the prosecution and the accused or his defence counsel entering into an agreement to resolve a criminal charge against the accused. The process is without trial where the accused pleads guilty to a lesser charge, or the accused pleads guilty to a particular lesser charge in exchange for the dismissal of other serious charge, or the accused pleads guilty to the charge for a lesser sentence. (G. Nicholas Herman, 2012, 2). The victim's presence is not necessary because the process merely involves the prosecutor and the accused or the advocate and matter or dispute is either on the offence charged or the sentence. Nevertheless, the prosecution has to consider the implication of crime on the victim when considering plea bargaining and its outcome (Maureen, 2004, 571).

Plea bargaining agreement may result the prosecutor agrees to withdraw or amend a charge against the defendant, or the defendant pleads guilty to a reduced charge, or the defendant pleads guilty to a particular charge in exchange for the dismissal of other charges, or the defendant pleads guilty as charged or to lesser charge in return for sentencing agreed by the prosecution, or the defendant enters a conditional plea of guilty reserving the right to appeal against the judgment. The plea bargain requires certain conditions on the accused such as to make restitution to the victim, refrain from the further offence, or giving testimony for the 
prosecution against the other accused (G. Nicholas Herman, 2012, 2).

\subsection{Plea bargaining under section $172 \mathrm{C}$ of the Criminal Procedure Code (Amendment) Act 2012 of Malaysia}

In Malaysia, section 172C of the Criminal Procedure Code allows plea bargaining to be exercised between the accused and the prosecutor regarding the charge or the sentence. Upon the application of plea bargaining made by the accused, the court shall issue a notice to the public prosecutor and to the accused to appear before the Court on a date fixed for the hearing of the application. If the court satisfied that the accused has made the application of plea bargaining voluntarily, the public prosecutor and the accused should start negotiation on a satisfactory disposition of the case. If the court found that the application is made involuntarily by the accused, the court shall dismiss the application and the case shall proceed before another court for trial (Baljit, 2011, 296).

During the negotiation process, the parties merely discuss whether to accept a plea on the reduction of sentence or offence. In case the accused and the prosecution agreed to a satisfactory disposition, it shall be put into writing and signed by the accused, the advocate and the public prosecutor. The court shall give effect to the satisfactory disposition as agreed upon by the accused and the public prosecutor. In other words, if the parties agree on a reduction to the charge, the accused has to plead guilty to the amended charge and the Court will pass sentence based on the new charge. If the parties agree to reduction of sentence, the Court will decide the sentence according to section 172D of the Criminal Procedure Code 2012. Otherwise, if no satisfactory disposition has been reached by the accused and the prosecution, the court shall record and the case shall proceed before another court for trial. (Baljit, 2011,296).This is to avoid bias from the judge if the same judge hears the trial.

The parties have no right to determine or discuss matters about the sentence as it will infringe the power of the Court to determine the sentence. In Public Prosecutor v Abdul Malik bin Abdullah [2013] 8 MLJ 251, Akhtar Tahir $\mathrm{J}$ observed that the judge would not simply imposes sentence as agreed by the parties in plea bargaining. Any agreement or plea bargaining as to sentence does not restrain the discretion of the judge in imposing the appropriate sentence based on the circumstances of the case. The judge quoted Wan Yahya $J$ in New Tuck Shen $v$ Public Prosecutor [1982] 1 MLJ 2, the deputy public prosecutor is allowed not to proceed with the case or amend the charge and it is the court to impose the sentence, to reduce or enhance it. It is submitted that the case has been qualified by the inserted provisions of plea bargaining.

If the satisfactory disposition is concerning the charge, the accused shall be guilty on a new charge as agreed and the accused shall be sentenced accordingly. However, if a satisfactory disposition is on sentence, the accused shall be guilty on the original charge. Subsequently, the Court may order the accused a lenient sentence as provides in the law such as to pay compensation to the victim, or to be dealt under youthful offenders or first offenders or to be sentenced not more than half of the maximum punishment of imprisonment provided in the law. Under the youthful offender, the accused can be discharged due to admonition, order good behaviour, order community service or whipping with a light cane. However, if the offence involved is a serious one, or sexual related offence, or the accused has a previous conviction for a related or same offence, the punishment of imprisonment shall not be less than half of the maximum punishment.

For example, in Ahmad Rashidi bin Zainol \& Anor v Public Prosecutor [2014] 9 MLJ 562, the Court highlights the effect of pleading guilty at plea bargaining process and before trial which stated that if the accused plead guilty before commencement of trial, the court shall sentence the accused in accordance with section 172(D)(1)(c)(ii) of the Criminal Procedure Code that is the sentence shall not be more than half of the maximum sentence of imprisonment. However, since in this case the accused claim trial until the end of the court proceeding, if the accused is found guilty and convicted, section 172(D)(1)(c)(ii) of the Criminal Procedure Code is not applicable.

Thus, plea bargaining is a criminal resolution process which allows the accused and the prosecutor to negotiate on reduction of the charge or the sentence on the accused. The implication is that no appeal is allowed if the parties reach an agreement.

\subsection{The role of a judge in the plea bargaining process}

The Code is silent on the involvement of the judge in the process of plea bargaining. The provision neither prohibits nor allow the judge to assist the parties reaching a satisfactory disposition for plea bargaining. However, as stated in section 172D of the Criminal Procedure Code, if the parties reached a satisfactory disposition, the court shall impose sentence accordingly. The parties have no idea about the sentence that ought to be imposed by the Court. Once the accused plead guilty, resulting from plea bargaining, the Court 
imposes sentence according to section 172D of the Criminal Procedure Code.

Nonetheless, some judges encourage and assist the parties in the process of plea bargaining, to reach an agreement and even decide for the parties in the chamber. If the parties agreed with the suggestion, the sentence would be imposed accordingly and the case is not brought to trial.

It can be seen in Public Prosecutor v Manimaran a/l Manickam [2011] 6 MLJ 534 where the Court of Appeal agreed that a judge shall be a party in plea bargaining and be free to indicate the maximum sentence if the accused person or his counsel sought an indication of the sentence which would be imposed on the accused. The judges suggested guidelines for plea bargaining as follows; (1) The request for plea bargaining must come from the accused person to the public prosecutor or the counsel with written authority signed by his client seeking for plea bargain on the sentence. (2) Both must reach an agreement on the sentence either the minimum or the maximum sentence and shall be put into writing. If the court agrees, the judge or magistrate should indicate his or her agreement to the parties. Moreover, the sentence imposed must be within the range agreed to between the parties. (3) If the court disagrees with the sentence suggested by the prosecution and the defense, it must inform the parties and indicate the sentence it would be imposing. It is up to the parties to decide on the next move. If there is no agreement, the case should go to trial. (4) The process of plea bargaining must be done transparently, and must be recorded. The judges also suggest that the accused and the prosecution must reach an agreement on the sentence and shall be put into writing. The sentence imposed must be within the range agreed to between the parties. If the court disagrees with the sentence suggested by the prosecution and the defense, it must inform the parties and indicate the sentence it would be imposing. It is up to the parties to decide on the next move. If there is no agreement, the case should go to trial.

Though a judge is not a party in the plea bargaining process, the judge plays a vital role in recording any information arises from the plea bargaining agreement. The accused and the prosecutor have to notify the court if plea bargaining agreement reached between them and specify whether it is on reduction of charge or sentence. Thus, the court will impose punishment on the accused accordingly as governed under section 127D under the Criminal Procedure Code.

\section{MEDIATING PLEA BARGAINING PROCESS}

Mediation is a form of alternative dispute resolution where the parties in the dispute assisted by a mediator who will facilitate communication between the parties to decide the dispute (Osborn's Concise Law Dictionary, 2009, 268) Mediation is a process where the parties with a neutral person develop options, consider alternatives, and reach a consensual settlement based on their needs (Jay and Alison, 1984,7). In the context of criminal law, mediation is a process where the offender and the victim participate in the mediation process with the assistance of a neutral third party to communicate about the crime, its consequence and to reach an agreement (Daniel, Karen, 2010,66).

Criminal mediation in case management process is an improvement in the plea bargaining system (Larysa, 2007,797). The presence of a judge acting as a neutral third party to facilitate the plea bargaining process reduces the probability and the dangers of immoral plea bargains. The use of mediation in criminal cases saves a lot of money, cut short the formal hearings, appeals and retrials (John, 2014). Many cases were resolved through court annexed mediation before a judge as a mediator since the judge has experience in handling criminal cases (Larysa, 2007,797).

In the mediation process, a neutral third party intervenes in the process after the parties' initial attempts at negotiation or plea bargaining have failed. The mediator having experienced in criminal cases might review the strengths and weaknesses of the case to encourage understanding of the facts and issues and may offer his opinion as a mediator (Larysa, 2007,797). The mediator is expected to assist the participants with analysis, to protect the defendant from coercion, to urge the participants to settle the case, and to preserve the integrity of the mediation process (Maureen, 2004, 571). The mediator could help the parties come up with an agreement that is acceptable to both sides.

The judge acting as a mediator in plea bargaining will reconcile the positions of the accused and the prosecution (Gabriel, 2009). The judge will facilitate the parties to reach an agreement without imposing any decision for them. The mediator helps the disputing parties to negotiate with each other, but does not negotiate with them. The mediator who is an expert in the subject matter is expected to assist the parties by persuading the parties to reach a mutual agreement, preserve the integrity of mediation, to ensure the process and the outcome is made in good faith without any coercion (Maureen, 571). It is an evaluative form of mediation. The implementation of criminal mediation in case management to facilitate the plea bargaining process can be seen in Singapore. 


\subsection{Criminal case resolution under the Registrar's Circular No.4 of 2011 of Singapore}

In Singapore, mediation in plea bargaining is known as criminal case resolution. The criminal case resolution has been introduced in 2009 and fully implemented under the Registrar's Circular No. 4 of 2011 as part of the Singapore criminal justice system. The objective of the criminal case resolution is to resolve criminal cases at an early stage through mediation facilitated by a senior judge (State Courts Annual Report, 2012, 6). At a criminal case resolution, the prosecution and the accused discuss the disputed issues that remain unresolved at the early stage. If the accused intends to plead guilty, the judge as a mediator will suggest a sentence to the parties. If agreed, the accused will be sentenced accordingly. Otherwise, the case will proceed to trial before another judge court.

In the Registrar's Circular No. 4 of 2011, mediation can only take place after the case had gone through the process of the criminal case management system, and then through the criminal case disclosure conference, and finally at the pre-trial conference. Criminal mediation is applicable if at all those stages, negotiation between the prosecution and the accused to resolve the case failed. Referral to mediation may be made by a pre-trial conference judge, a criminal case disclosure conference judge, or by the parties. If mediation is unsuccessful at the mediation stage, then the Court will have no further avenue but to fix the date for trial as the essence of mediation is voluntary between the prosecutor and the accused and the judge's role to facilitate the process.

A mediator must be a senior and experienced district judge with at least ten years' experience in hearing and determining criminal cases. A mediating judge is a not the same judge who presides over the criminal case management system, criminal case disclosure conference, and at the pre-trial conference. In case the parties fail to reach an agreement at the pre-trial conference, the parties will inform the judge they cannot agree to resolve the case. The pre-trial conference judge will fix the date for mediation before another judge who is also a competent mediator. The role of a judge during the criminal mediation is facilitative, and the mediating judge may encourage the parties to make disclosure and have an open discussion.

The mediator has the discretion to give a sentence indication if requested by the defense counsel. A sentence indication would only be given after the mediator has made an assessment of the case such as analyse the charge, the facts and the defendant's mitigation plea. Singapore does not give full freedom to the prosecutor and the accused or advocate discussing in the process of criminal mediation. This is because, a judge who acts as a mediator may assess and decide the sentence to the parties. Nevertheless, the prosecutor and the accused may suggest a sentence to the mediator or the accused may ask for a sentence indication from the mediator so that sentence to be imposed on the accused agreed by the prosecutor and the accused.

Hence, this reflects that plea bargaining can be facilitated by a judge, particularly if the parties agree to plea bargaining but unable to reach an agreement between the parties. Thus, the judge will assist the parties by listening to the suggestions made by the parties and may make suggestion on the sentence. The parties still have right to suggest the sentence or a new charge, and the judge acts as a mediator, will impose the decision as agreed by the parties.

\section{SUGGESTIONS AND RECOMMENDATIONS}

Having discussed the above, it can be seen that criminal resolution out of court can still be done through mediation if the negotiation process between the prosecutor and the accused at the plea bargaining fails. As implemented in Singapore, the same shall apply in Malaysia to allow the judge to assist the prosecutor and the accused to resolve criminal cases by way of mediation if the attempts of plea bargaining fail. Thus, criminal mediation can be applied in Malaysia especially to complement the process of plea bargaining. If there is mediation after an initial attempt of plea bargaining fails, the case can be referred to mediation before proceeding to trial. This can expedite the disposal of criminal cases, reduce pending cases as well as appeal cases. Plea bargaining without a neutral third party would likely render it difficult to reach a mutual agreement. This is because the prosecutor and the accused have different interests and needs, whereby the accused seeks a lenient sentence, whereas the prosecutor aims for a severe punishment. Thus, without the assistance of a neutral third party to assist the prosecutor and the accused in negotiating, it will be difficult to reach a mutual agreement. If a judge could act as a mediator assists the prosecutor and the accused or the advocate to reach a mutual agreement, by making sentence indication or discuss with the parties on the range of sentence agreed by them, the criminal case can be resolved without a trial. Thus, if criminal mediation is incorporated into the Criminal Procedure Code, this would complement the weaknesses and lacunas in the current process of plea bargaining. It is suggested that the Criminal Procedure Code of Malaysia to be amended to allow mediation to be implemented if the attempts of plea bargaining fail. As 
such, the prosecutor and the accused will have another option before proceeding to trial if they are unable to reach an agreement on the plea bargaining process.

\section{CONCLUSION}

Plea bargaining is an out of court criminal resolution which involves the prosecutor and the accused to reach an agreement, either to reduce the charge or the sentence. Nevertheless, it is difficult to reach an agreement between the accused and the prosecutor at the plea bargaining process since both parties have different interests and needs. However, through the mediation process assisted by a judge, the prosecutor and the accused can easily reach a deal since the judge may impose sentence indication to the parties and will impose the sentence as agreed by the parties. If an agreement is reached in the mediation, the offender will be subject to a lesser charge or reduction of punishment. It can be seen that Singapore has taken a proactive step in solving criminal cases through mediation if an agreement in plea bargaining fails to achieve. If the case cannot be resolved in the plea bargaining process, a mediator can hear the fact of the case, the disputed issues and facilitate the prosecutor and the accused to reach an agreement by giving a sentence indication or sentence the accused within the range agreed with the prosecutor and the accused. Hence, if the power of the Court in Malaysia is extended to act as a mediator, so that criminal cases, if unable to be resolved at plea bargaining process shall be referred to the mediator before proceeding to another Court for trial. However, litigation is still necessary if other criminal dispute resolution mechanisms do not resolve the criminal case.

\section{ACKNOWLEDGEMENT}

This research was financially supported by the Research Initiative Grant Scheme (RIGS) 2016 (Project ID RIGS16-252-0416).

\section{REFERENCE LIST}

Baljit Singh Sidhu. (2011). Criminal Litigation Process. Malaysia: Sweet \& Maxwell Asia.

Daniel W. V. N., \& Karen, H.S. (2010). Restoring Justice: An Introduction to Restorative Justice. New York:Routledge.

Gabriel, H. (2009). The Defense Attorney as Mediator in Plea Bargains. Pepperdine Dispute Resolution Law Journal, 9 (3).

G. Nicholas Herman, (2012). Plea Bargaining. New York: Juris Publishing.

Jay, F. \& Alison, T. (1984). Mediation: A Comprehensive Guide to Resolving Conflicts Without Litigation. USA: Jossey-Bass Publishers.

John, S. (2015). A Growing Alternative To Criminal Trials: Mediation Neutral Parties Show Crux Of Arguments To Prosecution,Defense. http://www.idahostatesman.com/2015/01/18/3597601/agrowing-alternative-to-criminal.html\#storylink=cpy.

John, S. (2008). A Practical Approach to Criminal Procedure. New York: Oxford.

Kimberlee, K. K. (2007). The State of Criminal Justice 2007-2008, Victor, S (Ed.). USA: American Bar Association.

Larysa, S. (2007). Criminal Mediation is the BASF of the Criminal Justice System: Not Replacing Traditional Criminal Adjudication, Just Making It Better. Ohio State Journal on Dispute Resolution. (22).

Laurence, B. \& Miryana, N. (2001). Mediation: Principles Process Practice. United Kingdom: Butterwoths.

Laurie, W. (2014). Criminal Mediation: Violating Victims' Rights?. http://magicvalley.Com/news/ local/criminal-mediation-violating-victims-rights/ article_583b36d1-6c20-505f-91aa 26adbdd527ac.html.

Maureen, E. L. (2004). Remarks On Case-Management Criminal Mediation. Idaho Law Review. (40).

Maureen, E. L. (2004). Case-Management Criminal Mediation Offers Promise But Requires Caution. The Advocate, http://digital.lib.uidaho.edu/cdm/ref/collection/lawir/id/167.

Message from the Chief District Judge, the State Courts Annual Report. (2012). 
IJASOS- International E-Journal of Advances in Social Sciences, Vol. III, Issue 7, April 2017

https://www.statecourts.gov.sg/Resources/Documents/AnnualReport2012.pdf.

Osborn's Concise Law Dictionary. (268). London: Sweet \& Maxwell.

Wan Arfrah Hamzah. (2009). A First Look at the Malaysian Legal System. Selangor: Oxford Fajar Sdn. Bhd. 